\title{
Etiology of Bull's Eye Rot of Pear Caused by Neofabraea spp. in Oregon, Washington, and California
}

Jose L. Henriquez and David Sugar, Oregon State University Southern Oregon Research and Extension Center, Medford 97502; and Robert A. Spotts, Mid-Columbia Agricultural Research and Extension Center, Hood River, OR 97031

\begin{abstract}
Henriquez, J. L., Sugar, D., and Spotts, R. A. 2004. Etiology of bull's eye rot of pear caused by Neofabraea spp. in Oregon, Washington, and California. Plant Dis. 88:1134-1138.

A collection of Neofabraea isolates from pear fruit grown in Oregon, Washington, and California was screened with species-specific primers in a multiplex polymerase chain reaction (PCR). Neofabraea alba was identified most frequently in samples from Oregon and California, whereas $N$. perennans was found most frequently in samples from Washington. $N$. alba also was identified from tissue of small cankers and pruning stubs on pear trees using PCR. Bull's eye rot pathogens were isolated from fruit of nine different European pear cultivars, Asian pear, and quince. Overall, $N$. alba was the most prevalent species in 2001 whereas $N$. perennans was more prevalent in 2002. An undescribed species of Neofabraea was identified in samples from Medford, OR that corresponds to a species previously found by others using molecular methods. This information increases the known geographic distribution of this undescribed species.
\end{abstract}

Additional keywords: canker diseases, Pyrus communis

Bull's eye rot of apple and pear, caused by species of Neofabraea, is an important postharvest disease in the Pacific Northwest (PNW) of the United States, and also occurs in Europe and other growing areas. Fruit can be infected in the orchard at any time during the growing season, and spores or incipient infections remain latent until development of symptoms after several months of postharvest storage $(5,12,25)$. On apple trees, bull's eye pathogens produce cankers on branches and twigs or develop saprophytically on dead wood, from which spores are produced and dispersed in splashing water to the fruit $(3,14,17,18,21)$.

Four species of the genus Neofabraea are known to cause bull's eye rot of apple (8). Neofabraea alba is the main pathogen causing bull's eye rot in continental Europe $(6,13)$, and also has been reported as a minor disease of apple in eastern North America (25). N. malicorticis causes anthracnose canker of apple trees and is found principally in the more humid areas of the PNW. It is an aggressive pathogen able to infect sound wood directly (20). $N$. perennans causes perennial canker of ap-

Corresponding author: D. Sugar

E-mail: david.sugar@oregonstate.edu

Financial support was provided by the Winter Pear Control Committee.

Accepted for publication 5 June 2004.

Publication no. D-2004-0730-01R

(C) 2004 The American Phytopathological Society ple trees. The pathogen requires wounds to infect the wood, and the fungus survives in cankers by infecting injured tissue at the border of old cankers $(7,20)$. N. malicorticis and $N$. perennans are considered a single species in Europe $(6,13,19,24)$, whereas they have been regarded as distinct species in North America $(9,10$, 17,20). A putative new species, yet to be described, recently has been reported in a phylogenetic study of Neofabraea spp. causing tree cankers and bull's eye rot of apple (8). It was represented by one isolate from Nova Scotia, Canada, and one from Portugal. The undescribed species also has been identified recently in a molecular study in Australia (J. Cunnington, personal communication).

There is no canker disease described on pear trees associated with the bull's eye rot pathogens, although pear has been mentioned as a host by some authors describing apple canker diseases (7). An association of bull's eye rot fungi with dead or injured pear bark also has been reported $(15,25)$.

Morphological differences among bull's eye pathogens are subtle and often overlap, making specific identification difficult and undependable. Several comparative studies on the morphology have been performed, especially to differentiate $N$. malicorticis from $N$. perennans $(9,10,20)$. Verkley $(26)$, in a world monograph of the genus $\mathrm{Pe}$ zicula, matched morphological characters with molecular data (restriction fragment length polymorphisms of nuclear rDNA) and revalidated the genus Neofabraea. Abeln et al. (1) conducted a phylogenetic study of Pezicula, Dermea, and Neo- fabraea by partial sequencing of ribosomal RNA genes, and concluded that Neofabraea is a separate evolutionary lineage and should not be included among $\mathrm{Pe}$ zicula. Later, de Jong et al. (8) identified four species of Neofabraea associated with apple tree cankers and bull's eye rot, including $N$. alba, N. malicorticis, $N$. perennans, and the putative new species. They found genetic differences between $N$. malicorticis and $N$. perennans that merited the recognition of these taxa as distinct species. Furthermore, they developed speciesspecific primers by sequencing the $\beta$-tubulin gene for the five known species of $\mathrm{NeO}$ fabraea, including N. krawtzewii, a pathogen of poplar trees. Gariepy et al. (16) established the protocol for a multiplex polymerase chain reaction (PCR) for the specific identification of bull's eye rot pathogens using mycelium from cultures or diseased tissue.

The objective of this study was to determine the species of Neofabraea causing bull's eye rot of pear grown in Oregon, Washington, and California using molecular and morphological techniques. Sources of inoculum on pear trees also were investigated in a PCR screening.

\section{MATERIALS AND METHODS}

Collection and storage of isolates. In 2001, 450 isolates of bull's eye rot fungi were accumulated for PCR identification. Pear fruit showing symptoms of bull's eye rot were collected from packinghouses in Medford and Hood River, OR (including the White Salmon area of Washington). Additional samples were obtained from the orchards of the Southern Oregon Research and Extension Center (SOREC), several commercial orchards in Medford, and from the Mid-Columbia Agricultural Research and Extension Center in Hood River. Cultures of fungi isolated from pear fruit with bull's eye rot from elsewhere in Washington and a small number of symptomatic pear fruit from Philo, CA were included. In addition, fruit from nine different pear cultivars from the orchards of SOREC were screened to evaluate possible differential cultivar susceptibility.

In 2002, 205 pear fruit with bull's eye rot obtained from four orchards in Medford and one orchard in Hood River were screened and the causal agents identified as $N$. alba or $N$. perennans based on the morphology of their macroconidia. 
Direct tissue isolations were performed from fruit that had been surface sterilized in $0.5 \%$ sodium hypochlorite. Alternatively, monosporic cultures were obtained when sporulation was present. Monosporic cultures were made by immersing an individual fruiting body, extracted from a fruit lesion, in 100 to $300 \mu \mathrm{l}$ of sterile distilled water and subsequently spreading the suspension on water agar. The cultures then were incubated at approximately $4{ }^{\circ} \mathrm{C}$ for 1 to 2 weeks. Individual germinating conidia then were transferred to acidified potatodextrose agar (aPDA) in petri dishes. Morphology of the germinating conidia and presence or absence of microconidia were noted. Isolates were stored at $4{ }^{\circ} \mathrm{C}$ until molecular screening.

Sampling of woody tissues. In all, 60 samples each of dead bark, pruning stubs, previous-season fruit spurs, and 72 samples of small superficial cankers were taken from a block of Bosc pear trees with a history of bull's eye rot in an orchard at SOREC. These woody tissues were screened using PCR and Neofabraea species-specific primers in order to detect the presence of bull's eye pathogens and to determine possible inoculum sources on pear trees.

DNA extraction. Total genomic DNA was extracted using the FastDNA Kit, following manufacturer's instructions (Qbiogene, Carlsbad, CA). Approximately 200 $\mathrm{mg}$ of mycelium from cultures growing on aPDA were transferred to FastPrep 2-ml tubes containing $800 \mu \mathrm{l}$ of cell lysis buffer solution for plant samples (CLS-VF) and $200 \mu \mathrm{l}$ of protein-precipitating solution to eliminate inhibitors that could be present in the culture media. Samples were processed in a FastPrep machine (FP 120) for $30 \mathrm{~s}$ at speed 4 , incubated for $15 \mathrm{~min}$ at room temperature, and extracted following the protocol for CLS-VF buffer. DNA extraction from pear tree woody tissues was conducted as described above but at speed 5 , incubated for $30 \mathrm{~min}$ at room temperature, and extracted according to the protocol for CLS-VF buffer. The extraction product containing total DNA then was subjected to a second extraction using CLS-Y buffer (cell lysis solution for yeasts, algae, and fungi) for the extraction of fungal DNA.

DNA amplification. Amplification of DNA was performed in a multiplex reaction, with the addition of four speciesspecific primers simultaneously, following the protocol developed by Gariepy et al. (16). The species-specific primer sets use the same forward primer in combination with the specific reverse primer. PCR reactions were conducted in $200-\mu \mathrm{l}$ tubes in a GeneAmp PCR system 2700 (Applied Biosystems, Foster City, CA). A total of 25 $\mu \mathrm{l}$ of reaction solution contained $0.2 \mu \mathrm{l}$ of $10 \mathrm{mM}$ dNTPs; $0.1 \mu \mathrm{l}$ of $5 \mu \mathrm{M}$ of the universal fungal primers UN-UP18S-42 and UN-LO28S-22 (2), which amplify a por- tion of the internal transcribed spacer region and were used as positive control to demonstrate the presence of fungal DNA after the extraction; $0.4 \mu \mathrm{l}$ of $20 \mu \mathrm{M}$ of the forward primer; $0.4 \mu \mathrm{l}$ of a $5-\mu \mathrm{M}$ solution of each of four species-specific primers; $0.5 \mu \mathrm{l}$ of $\mathrm{Taq}$ titanium DNA polymerase and $2.5 \mu \mathrm{l}$ of $10 \times$ titanium Taq PCR buffer (Clontech Lab., Palo Alto, CA); and distilled water to the final volume. The PCR reaction was performed using four different annealing temperatures to achieve higher specificity. It consisted of an initial denaturation step of $3 \mathrm{~min}$ at $95^{\circ} \mathrm{C}$ followed by 40 cycles of $45 \mathrm{~s}$ at $95^{\circ} \mathrm{C}, 45 \mathrm{~s}$ at four different annealing temperatures, and $2 \mathrm{~min}$ at $72^{\circ} \mathrm{C}$, with a final extension of 10 min at $72^{\circ} \mathrm{C}$. The annealing temperatures started at $72^{\circ} \mathrm{C}$ for 5 cycles and decreased to 70 and $68^{\circ} \mathrm{C}$ for 5 cycles each and to $66^{\circ} \mathrm{C}$ for 25 cycles. Isolates where DNA could not be amplified in PCR reactions were identified using morphological characteristics.

Agarose gel electrophoresis and visualization of PCR products. PCR products were resolved on $1.5 \%$ agarose gels stained with ethidium bromide and visualized by UV transillumination at $302 \mathrm{~nm}$.
Band sizes resulting from the PCR reaction were estimated based on a low mass DNA ladder (Gibco/Invitrogen, Carlsbad, CA).

\section{RESULTS}

Molecular identification of bull's eye rot isolates from pear fruit. A total of 450 isolates from pear fruit showing symptoms of bull's eye rot were screened with PCR. DNA fragment sizes of 358,300 , and 236 bp were obtained, consistent with those previously amplified for $N$. alba, $N$. perennans, and the undescribed Neofabraea sp. respectively (16; Fig. 1).

$N$. alba was the most common species isolated, with a total of 282 isolates identified in samples from Oregon and California (Table 1). N. perennans was the second most common species, and was identified from 95 isolates originating in Wenatchee, WA and Hood River and Medford, OR. Eighteen isolates of the undescribed $\mathrm{NeO}$ fabraea sp. were found, obtained from 10 orchards in the Medford area. Fourteen isolates were identified as Cylindrocarpon magnusianum Wollenweb. based on morphological characters. The Neofabraeaspecific primers did not amplify any fragment of DNA from these isolates, but uni-

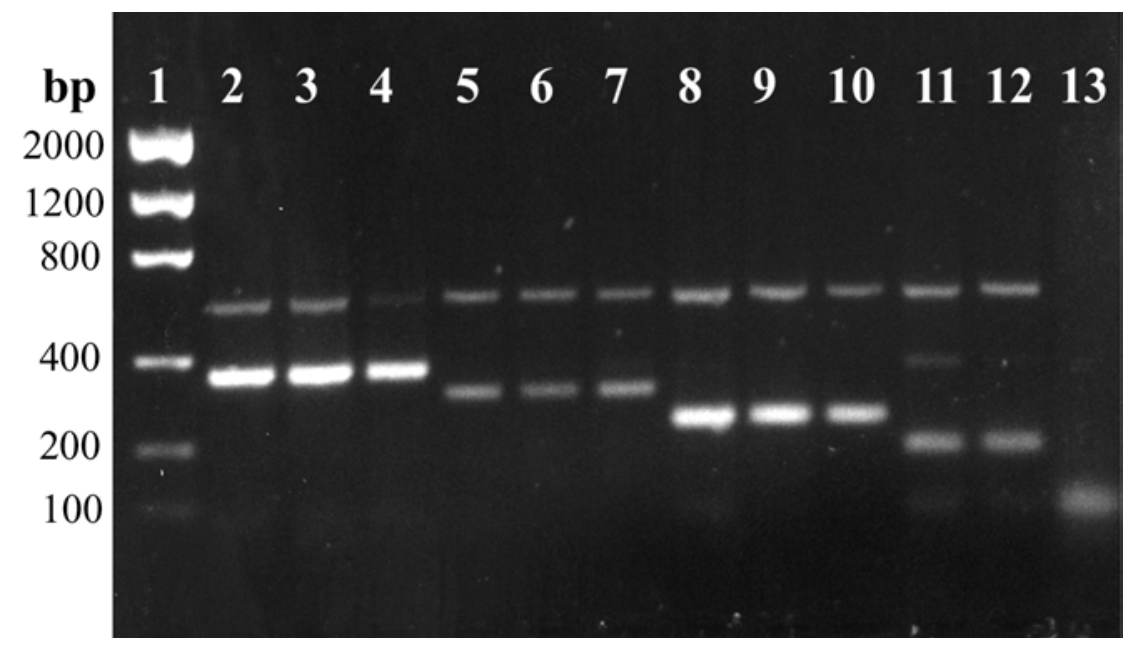

Fig. 1. DNA fragments from polymerase chain reaction products of the Neofabraea spp. isolated from bull's eye rot lesions on pear fruit. Lane 1: a low-mass DNA ladder (Invitrogen, Inc. Rockville, MD); lanes 2-4: N. alba (isolates MB-0202, MB-0203, and MB-0204); lanes 5-7: N. perennans (isolates MB-0274, MB-0278, and MB-0279); lanes 8-10: undescribed Neofabraea sp. (isolates MB-0222, MB-02109, and MB-02127); lanes 11-12: N. malicorticis (from cankers on Newtown apple trees, Hood River, OR); lane 13: negative control. A band at approximately $600 \mathrm{bp}$ in lanes 2-12 corresponds to a fungal universal band used as control for positive DNA extraction.

Table 1. Molecular identification of pathogens isolated from bull's eye rot lesions on pear fruit from different sources in the western United States

\begin{tabular}{|c|c|c|c|c|c|}
\hline Pathogen & $\begin{array}{l}\text { Wenatchee, } \\
\text { WA }\end{array}$ & $\begin{array}{l}\text { Hood River, } \\
\text { OR }^{\mathbf{a}}\end{array}$ & $\begin{array}{l}\text { Medford, } \\
\text { OR }\end{array}$ & California & Total \\
\hline Neofabraea alba & 0 & 42 & 236 & 4 & 282 \\
\hline N. perennans & 18 & 28 & 49 & 0 & 95 \\
\hline Neofabraea undescribed species & 0 & 0 & 18 & 0 & 18 \\
\hline Cylindrocarpon magnusianum & 5 & 1 & 8 & 0 & 14 \\
\hline Not determined & 0 & 0 & 20 & 0 & 20 \\
\hline Mixed reaction ${ }^{b}$ & 10 & 0 & 11 & 0 & 21 \\
\hline Total number of samples & 33 & 71 & 342 & 4 & 450 \\
\hline
\end{tabular}

${ }^{a}$ Including the White Salmon area of Washington.

${ }^{\mathrm{b}}$ Isolates giving one band for $N$. alba and one band for $N$. perennans. 
versal bands were obtained. Twenty-one isolates gave a mixed reaction where DNA bands specific for both $N$. alba and $N$. perennans were amplified. The primer sets failed to amplify DNA samples from 20 isolates, despite being screened twice. In addition, eight isolates from apple fruit of unknown cultivars were identified as $N$. $a l b a$, whereas one was identified as the undescribed Neofabraea sp. All of the apple fruit were grown in the orchard of SOREC in Medford.

Bull's eye rot lesions, caused by either $N$. alba, $N$. perennans, or the undescribed Neofabraea sp., were observed on nine different pear (Pyrus communis) cultivars (Bosc, Comice, d'Anjou, Packham's Triumph, Red Anjou, Red Comice, Rogue Red, Seckel, and Winter Nelis), quince (Cydonia oblonga), and Asian pear ( $P$. pyrifolia, unknown cultivar) (data not shown).

Germinated macroconidia of $N$. perennans produced microconidia abundantly in culture media. In contrast, germinated macroconidia of $N$. alba did not produce microconidia and their mycelia grew faster and branched more repeatedly than those of $N$. perennans (Fig. 2). These criteria were used in preliminary identification of 194 isolates as $N$. perennans or $N$. alba. when monocultures for molecular identification were prepared. An $85.1 \%$ match was obtained between identification based on morphological criteria and molecular identification as $N$. perennans or $N$. alba. Thirteen of the isolates morphologically identified as $N$. perennans were molecularly identified as the undescribed Neofabraea sp. Production of microconidia from germinating macroconidia of the undescribed Neofabraea sp. was confirmed (Fig. 2).

In 2001, $80.8 \%$ of the bull's eye rot samples collected were found to be infected by $N$. alba (Table 2). In contrast, $N$. alba was identified from only $8.3 \%$ of bull's eye rot lesions in the 2002 season, whereas most lesions yielded $N$. perennans. All orchards except one in 2002 had

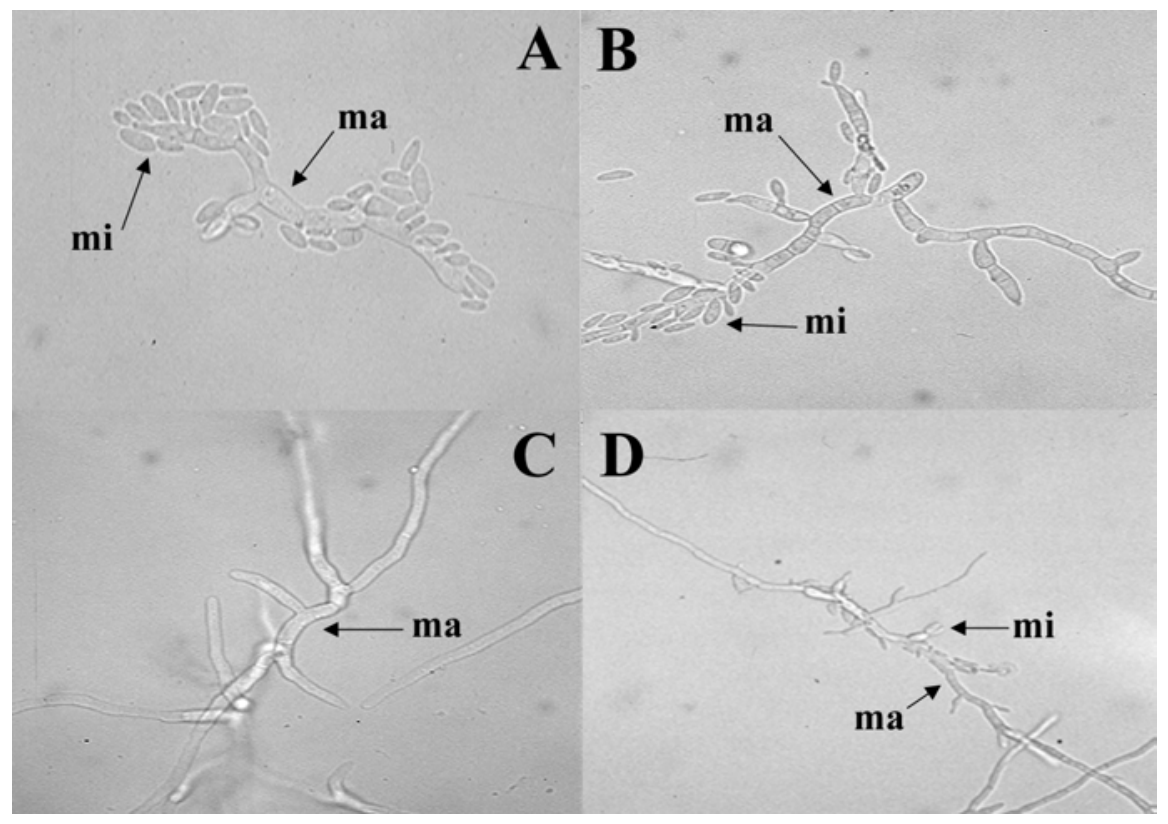

Fig. 2. Germinated macroconidia and production of microconidia by Neofabraea spp. causing bull's eye rot of apple and pear. A, N. malicorticis; $\mathbf{B}$, N. perennans; C, N. alba (does not produce microconidia); D, undescribed Neofabraea $\mathrm{sp} . \mathrm{Ma}=$ macroconidia and $\mathrm{mi}=$ microconidia. A, B, and $\mathbf{C}, \times 400$; D, $\times 250$.

Table 2. Identity of Neofabraea isolates causing bull's eye rot of pear in 2001 and $2002^{\mathrm{a}}$

\begin{tabular}{lccccc}
\hline & \multicolumn{3}{c}{ N. alba } & & \multicolumn{2}{c}{ N. perennans } \\
\cline { 2 - 3 } \cline { 5 - 6 } Orchard $^{\mathbf{b}}$ & $\mathbf{2 0 0 1}$ & $\mathbf{2 0 0 2}$ & & $\mathbf{2 0 0 1}$ & $\mathbf{2 0 0 2}$ \\
\hline Bybee (M) & 20 & 2 & & 0 & 36 \\
Fairlane (M) & 17 & 4 & & 0 & 5 \\
Hanley (M) & 85 & 4 & & 14 & 39 \\
Klamath (M) & 13 & 1 & & 0 & 15 \\
MCAREC (HR) & 42 & 6 & & 28 & 93 \\
Total & 177 & 17 & & 42 & 188 \\
\hline
\end{tabular}

${ }^{a}$ Identification of isolates from 2001 was based on DNA differences. Identification of isolates from 2002 was based on the morphology of macroconidia.

${ }^{\mathrm{b}} \mathrm{M}=$ Medford, $\mathrm{OR}$ and $\mathrm{HR}=$ Hood River, $\mathrm{OR}$.

${ }^{\mathrm{c}}$ Isolates from several Hood River orchards collected by the Mid-Columbia Agricultural Research and Extension Center (MCAREC) were screened in 2001 and from one orchard in 2002. a lower proportion of fruit infected by $N$. alba.

Sources of inoculum on pear trees. $N$. alba was positively identified in five samples of small cankers and four samples of pruning stubs (Fig. 3). None of the samples of dead bark or previous year's fruiting spurs gave a positive reaction. Neither $N$. malicorticis, $N$. perennans, nor the undescribed Neofabraea sp. were found in any woody sample from pear trees.

\section{DISCUSSION}

$N$. alba was the most common species isolated from bull's eye rot lesions on pear fruit. This species was listed previously by Shaw (23) by its anamorphic name Phlyctema vagabunda as found on Malus sylvestris Mill. in Washington State. In the present study, it was the prevalent species in 2001 in Oregon and the only one present in samples from California, although only a few samples were obtained from California. It was not found in isolates from Washington and, thus, may be more prevalent in the southern range of the area of study.

$N$. alba may have been present in the PNW for a long time. In 1925, Fischer (14) questioned the species composition of bull's eye rot fungi in apple fruit, because some isolates failed to produce spores in culture and could not be identified. Bompeix (4) found that alternating light and temperature regimes were necessary to induce sporulation by $N$. alba in culture. It is likely that this species historically has been confused with $N$. malicorticis, because both produce curved macroconidia on fruit lesions. Most of the literature on bull's eye rot of apple and pear indicates $N$. malicorticis as the causal agent, an identification probably based on the shape of the macroconidia $(22,25,28)$. N. alba was identified causing bull's eye rot of apple grown in Medford during the present study; therefore, this fungus also may be more important than previously considered as part of a pathogen complex that causes bull's eye rot of apple in the PNW. N. perennans was the second most prevalent species associated with bull's eye rot of pear, and its widespread distribution is consistent with what has been previously reported for apple (20).

The undescribed Neofabraea sp. was found in pear fruit from 10 different orchards. In all of these orchards sampled, at least one other Neofabraea sp. was present. In six of the orchards, all three species were found. In all cases, the undescribed Neofabraea sp. was the least frequent species, and was found only in southern Oregon. This species could be more restricted in geographic distribution, but a larger sampling of the areas where it was not found will be necessary in order to determine its presence or absence. Macroconidia of the undescribed Neofabraea sp. were similar in appearance to those of $N$. perennans. Microconidia were found 
among macroconidia in acervuli and were observed being directly produced by germinating macroconidia. Superficial mycelia frequently grew over the bull's eye rot lesions caused by the undescribed Neofabraea sp. and $N$. perennans, but this was not observed for $N$. alba.

$N$. malicorticis was not found causing bull's eye rot of pear in this survey. This fungus was reported by de Jong et al. (8) on Pyrus spp. from British Columbia and was described by Kienholz (20) as restricted to areas of the PNW west of the Cascade Mountains. It is possible that this species is confined to higher rainfall areas of the PNW. A more extensive survey of fruit from the Hood River-White Salmon and Willamette Valley areas, where $N$. malicorticis has been reported, would be needed to verify the importance of $N$. $m a$ licorticis as a pathogen of pear.
$N$. perennans was not found in any sample of woody pear tissues, despite its association with cankers in apple (11), whereas $N$. alba was found in both small cankers and pruning stubs. Differential conditions for establishment and sporulation on plant surfaces and in infected tissue among growing seasons may determine the relative prevalence of Neofabraea spp. as agents of fruit rot. $N$. perennans was reported as less important than N. alba on apple in Great Britain in the 1930s, but then became the more prevalent cause of bull's eye rot by the 1950s. Wilkinson (27) speculated that this situation resulted from the progressive colonization of injured wood, especially pruning wounds; thus, $N$. alba subsequently became more prevalent as a fruit rot. The finding that $N$. perennans apparently does not induce cankers on pear trees under natural conditions could ex-

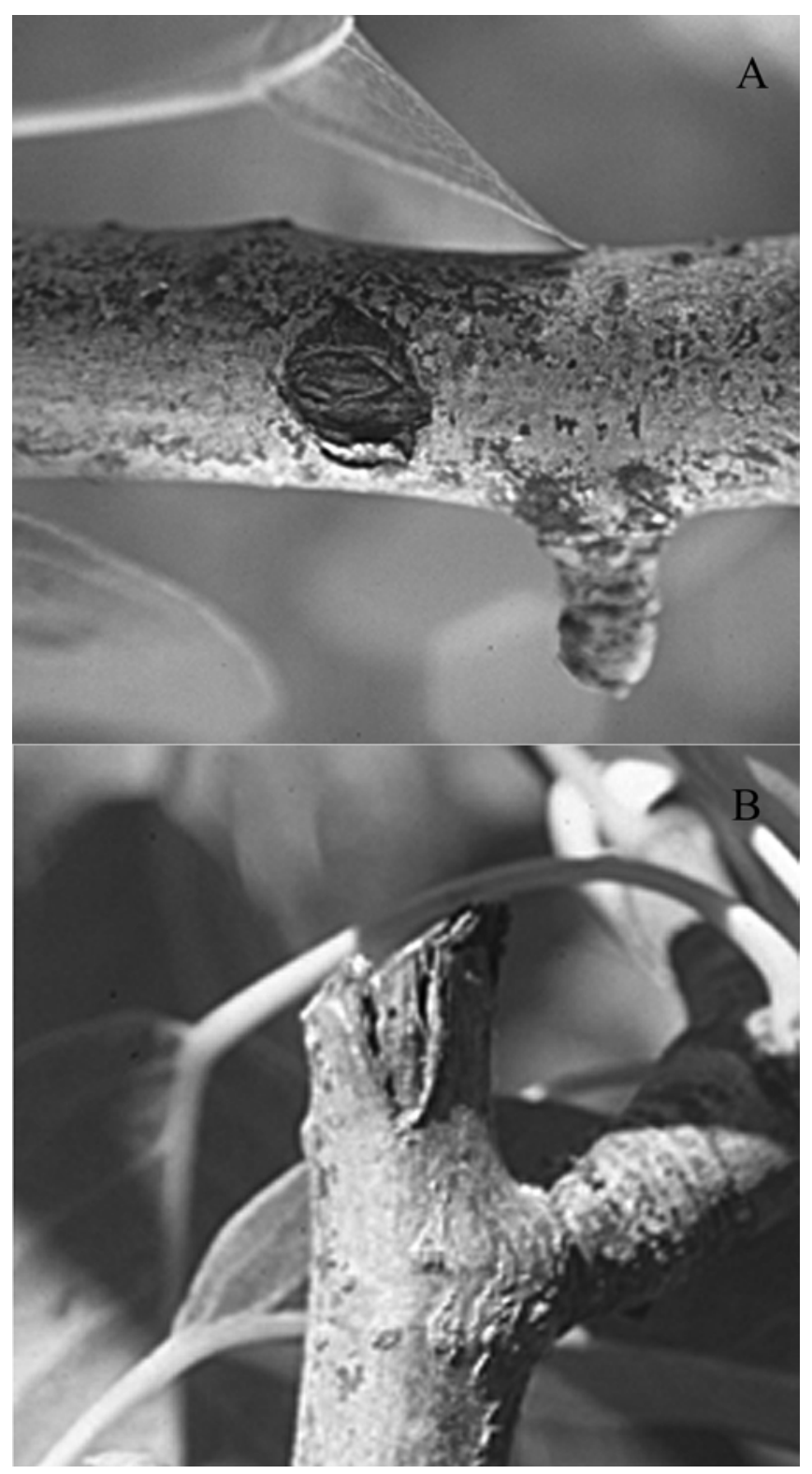

Fig. 3. Woody tissues from which Neofabraea alba was identified in a polymerase chain reaction with species-specific primers. A, Small superficial canker on a branch of a Bosc pear tree. B, Pruning stub showing a small necrotic zone on a branch of a Bosc pear tree.

plain its relatively lower importance than N. alba in pear orchards. Climatic factors also may influence the prevalence of a given species of Neofabraea.

The production of microconidia by the germinating macroconidia of $N$. perennans but not by those of $N$. alba is consistent with the observations of Wilkinson (27). Combined with the morphological differences between the macroconidia of these species, this criterion should be adequate to differentiate these two species. However, germinating macroconidia of the undescribed Neofabraea sp. also produced microconidia, and their shape is similar to those of $N$. perennans; thus, differentiation of these two species appears to require application of molecular techniques. Germinating macroconidia of $N$. malicorticis produce microconidia as well, but it may be differentiated from $N$. perennans by the curvature of its macroconidia, and possibly by geographical distribution and host specificity.

Isolation of bull's eye rot pathogens from nine cultivars of European pear as well as Asian pear and quince suggests that bull's eye rot susceptibility may be widespread in Pyrus spp. and related genera. However, because the disease commonly appears only after four or more months in cold storage (25), practical importance of the disease excludes many pear cultivars that do not store for long periods of time, including Bartlett.

The identification of three species causing bull's eye rot of pear raises new questions regarding their comparative epidemiology and control. The different species coexist with each other and their relative importance from one season to another may be influenced by weather conditions or other factors. How cultural practices in the orchard affect fruit infections by each of the pathogens is important to know in order to design appropriate control measures.

\section{ACKNOWLEDGMENTS}

We thank C. L. Xiao, P. Sanderson, and R. Elkins for providing Neofabraea isolates; and J. Kerrigan for identification of Cylindrocarpon magnusianum.

\section{LITERATURE CITED}

1. Abeln, E. C. A., de Pagter, A., and Verkley, G. J. M. 2000. Phylogeny of Pezicula, Dermea, and Neofabraea inferred from partial sequences of the nuclear ribosomal RNA gene cluster. Mycologia 92:685-693.

2. Bakkeren, G., Kronstad, J. W., and Levesque, C. A. 2000. Comparison of AFLP fingerprinting and ITS sequences as phylogenetic markers in Ustilaginomycetes. Mycologia 92:510-521.

3. Barrs, H. P. 1925. Northwestern apple tree anthracnose canker and fruit rot (Neofabraea malicorticis). Oreg. Agric. Coll. Ext. Serv. Circ. 220.

4. Bompeix, G. 1974. Action de la lumière et de la tempèrature sur le comportement du Pezicula alba Guthrie et du P. malicorticis (Jacks) Nann. in vitro. Ann. Phytopathol. 6:13-24.

5. Bompeix, G. 1978. Quelques aspects physiologiques des relations hote-parasite durant la 
conservation des pommes. Fruits 33:22-26.

6. Bompeix, G., and Cholodowski-Faivre D. 2000. Thermotherapie et produits naturels, une technologie emergente. L'arboriculture frutiere 542:19-25.

7. Childs, L. 1929. The relation of woolly apple aphis to perennial canker infection with other notes on the disease. Oreg. Agric. Exp. Stn. Bull. 243.

8. de Jong, S. N., Lévesque, C. A., Verkley, G. J. M, Abeln, E. C. A., Rahe, J. E., and Braun, P. G. 2001. Phylogenetic relationships among Neofabraea species causing tree cankers and bull's eye rot of apple based on DNA sequencing of ITS nuclear rDNA, mitochondrial rDNA, and the $\beta$-tubulin gene. Mycol. Res. 105:658-669.

9. Dugan, F. M., Grove, G. G., and Rogers, J. D. 1993. Comparative studies of Cryptosporiopsis curvispora and $C$. perennans. I. Morphology and pathogenic behavior. Mycologia 85:551564.

10. Dugan, F. M., Grove, G. G., and Rogers, J. D. 1993. Comparative studies of Cryptosporiopsis curvispora and C. perennans. II. Cytology and vegetative compatibility. Mycologia 85:565573.

11. Edney, K. L. 1956. The rotting of apples by Gloeosporium perennans Zeller and Childs. Ann. Appl. Biol. 44:113-128.

12. Edney, K. L. 1958. Observations on the infection of Cox's Orange Pippin apples by Gloeo- sporium perennans Zeller and Childs. Ann. Appl. Biol. 46:622-629.

13. Edney, K. L. 1983. Top fruit. Pages 43-71 in: Post-harvest Pathology of Fruits and Vegetables. C. Dennis, ed. Academic Press, New York.

14. Fisher, D. F. 1925. A new apple rot disease "Bull's eye rot"-caused by Gloeosporium Zeller \& Childs. Proc. Wash. State Hortic. Assoc. 21:44-48.

15. Fisher, D. F., and Reeves, E. L.1928. Perennial canker. Proc. Wash. State Hortic. Assoc. 24:5561.

16. Gariepy, T. D., Lévesque, C. A., de Jong, S. N., and Rahe, J. E. 2003. Species-specific identification of the Neofabraea pathogen complex associated with pome fruits using PCR and multiplex DNA amplification. Mycol. Res. 107:528-536.

17. Grove, G. G. 1990. Anthracnose and perennial canker. Pages 36-38 in: Compendium of Apple and Pear Diseases. A. L. Jones and H. S. Aldwinckle, eds. American Phytopathological Society, St. Paul, MN

18. Grove, G. G., Dugan, F. M., and Boal, R. J. 1992. Perennial canker of apple: Seasonal host susceptibility, spore production, and perennation of Cryptosporiopsis perennans in infected fruit in eastern Washington. Plant Dis. 76:1109-1114.

19. Guthrie, E. J. 1959. The occurrence of Pezicula alba sp. nov. and P. malicorticis, the perfect states of Gloeosporium album and $G$. perennans, in England. Trans. Br. Mycol. Soc. 42:502-506.

20. Kienholz, J. R. 1939. Comparative study of the apple anthracnose and perennial canker fungi. J. Agric. Res. 59:635-665.

21. McLarty, H. R. 1933. Perennial canker of apple trees. Can. J. Res. 8:492-507.

22. Salunkhe, D. K., and Desai, B. B. 1986. Postharvest Biotechnology of Fruits. Vol. I. CRC Press, Boca Raton, FL.

23. Shaw, C. G. 1972. Host fungus index for the Pacific Northwest-I. Hosts. Wash. State Agric. Exp. Stn. Bull. 765.

24. Snowdon, A. L. 1990. A Color Atlas of PostHarvest Diseases and Disorders of Fruits and Vegetables. Vol. 1: General Introduction and Fruits. CRC Press, Boca Raton, FL.

25. Spotts, R. A. 1990. Bull's eye rot. Page 56 in Compendium of Apple and Pear Diseases. A L. Jones and H. S. Aldwinckle, eds. American Phytopathological Society, St. Paul, MN.

26. Verkley, G. J. 1999. A monograph of the genus Pezicula and its anamorphs. Stud. Mycol. 44:1-176.

27. Wilkinson, E. H. 1954. Fungal rots of apples with special reference to Gloeosporium spp. Ann. Appl. Biol. 41:354-358.

28. Wilson, E. E., and Ogawa, J. M. 1979. Fungal, bacterial, and certain non-parasitic diseases of fruit and nut crops in California. Div. Agric. Sci. Univ. Calif., Berkeley. 